\title{
What facilitates students' active engagement in learning English in the classroom? Causal analysis between psychological needs, English classroom motivation and engagement
}

\author{
TANAKA, Hiroaki \\ Hiroshima International University
}

\begin{abstract}
The purpose of this study was to examine the facilitating factors of intrinsic English classroom motivation and students' classroom engagement. On the basis of Self-determination theory and the hierarchical model of motivation, this study examined the causal relationship between psychological needs and classroom engagement mediated by classroom motivation. Motivation is defined in terms of a Japanese EFL classroom context and intrinsic aspect, named intrinsic English classroom motivation, to differentiate trait motivation that most preceding studies on motivation have addressed. The participants were 69 high school students. Correlational and causal analyses revealed that the need for competence was (1) the strongest facilitating effect on intrinsic English Classroom motivation, and (2) the strongest indirect effect on classroom engagement. Moreover, the result showed that (3) the need for relatedness was an important facilitating factor of both intrinsic English Classroom motivation and classroom engagement. These results have implications for theories of motivation and also suggest one pathway by which teachers can facilitate students' classroom motivation and engagement in school.
\end{abstract}

\section{Introduction}

Students vary considerably in their engagement in their schoolwork. How can English teachers facilitate their students' active engagement in their classroom?

Recent motivational researchers have analyzed practical aspects of motivation by focusing on ways to facilitate students' motivation (e.g. Hiromori \& Tanaka, 2006; Tanaka \& Hiromori, 2007). These studies have revealed that students' motivation can be enhanced by the teacher's educational intervention. However, these studies do not include students' attitudinal variables. Thus, the present study was designed to examine the facilitating factors of students' classroom engagement as well as classroom motivation. 
In order to achieve the research purpose, motivation has to be defined with regard to the classroom context. However, research on contextual or situation-specific motivation is quite limited (Dörnyei, 2001). Thus, I begin this study by giving a clear definition of classroom motivation.

\section{Background study \\ Trait motivation vs. classroom motivation}

Most of the preceding studies on motivation define motivation as a trait attribute. Trait motivation generally refers to a relatively stable motivational attribute (Tremblay, Goldberg, \& Gardner, 1995). Though they defined trait motivation in terms of temporal duration, Fridhandler (1986) added a more detailed definition of trait. The concept of trait, according to his conceptualization, was adapted to a personal causal context. In other words, the concept of trait has been defined without regard to the current situation or, more commonly, without explaining individual differences in behavioral responses to a given situation (Spielberger, Auerback, Wadsworth, Dunn, \& Taulbee, 1973).

For example, when the research focuses on learners' trait motivation researchers would ask the learners about their feelings toward or reasons for learning English in general and do not ask about specific occasions or situations such as in English classrooms at school. Most of the preceding studies targeting Japanese EFL learners assess motivation in general, not motivation in a specific context or situation (e.g., Hiromori, 2003; Kimura, Nakata, \& Okumura, 2001).

However, motivation is a complex construct, and for more detailed understanding, motivation has to be addressed at various levels of generality. In order to clarify the complexity, it would be valuable to provide an example.

Take the case of a high school student named $\mathrm{A}^{1}$. In general, she is the kind of student who engages in learning English because of the pleasure and interest in learning English. Her motivation in general, or trait motivation, is presumed to be strong. She hopes to travel abroad after she graduates from high school and has a special interest in speaking English. Consequently, she likes Oral Communication class and engages in the communication activity enthusiastically. However, she is not interested in learning grammar at all. When her teacher starts to explain grammatical functions, she cannot concentrate well. Thus, she does not like Reading class because her teacher always focuses on translation. In this case, how can her motivation in school be assessed? Her motivation in Oral Communication class seems to be strong, though this is not the case with Reading class. Is it appropriate to define motivation as a trait concept? Therefore, for a better explanation of students' motivation in the classroom, and to achieve the goal of the present study, motivation has to be addressed in a more situation-specific way.

However, the number of motivational studies on situational and fluctuating motivation is quite limited (Dörnyei, 2001). In psychology, Vallearand and Ratelle (2002)'s hierarchical model addresses the multiplicity of ways to represent motivation differing in levels of generality. According to Vallerand and Ratelle (2002), motivation occurs at three different 
levels of generality: global, contextual, and situational. These three levels of motivation constitute a hierarchy in which the most general form of motivation is placed at the global level, and the most situation-specific form of motivation is at the situational level. Motivation at the contextual level lies in the middle of the hierarchy. This refers to motivation that is "influenced by contextual determinants and leads to contextual consequences" (Vallerand \& Ratelle, 2002, p. 45). I adopt his conceptualization of motivation with regard to level of generality. In this study, I use the term English classroom motivation to refer to students' motivation in a classroom context. Since Vallerand and Ratelle used the term context as a distinct sphere of human activity, following Emmons' (1995) proposition, English classroom motivation is assumed to be a subcomponent of motivation at a contextual level.

Although trait motivation and classroom motivation are conceptually distinguishable, there needs to be empirical evidences. Tanaka (2005a) conducted a questionnaire survey and analyzed the relationship between English Classroom Motivation and trait motivation. Participants were 291 high school students studying English as a foreign language. The result of exploratory factor analysis and confirmatory factor analysis showed that English Classroom Motivation was distinguishable from trait motivation.

\section{The qualitative aspect of classroom motivation}

In the preceding section, I defined motivation in terms of level of generality. In this section the qualitative aspect of motivation is discussed.

Much of the literature on motivation addresses the qualitative aspect of motivation in terms of intrinsic motivation, extrinsic motivation, and integrative motivation. Although not explicitly stated, the literature addresses these types of motivation as trait attributes. Most researchers, for example, ask the participants about their intrinsic or extrinsic reasons for learning English in general. This means they are assessing learners' intrinsic, extrinsic, or integrative trait motivation.

Discussion on the qualitative aspect of classroom motivation can be seen in Dörnyei (1994). He conceptualized classroom motivation with respect to interest, relevance, expectancy, and satisfaction. Interest is defined as "the individual's inherent curiosity and desire to know more about him or herself and his or her environment" (p. 277), which is related to the intrinsic aspect of classroom motivation.

Table 1.

Two way of defining motivation and motivation addressed in this study.

\begin{tabular}{|c|c|c|c|c|}
\hline & & \multicolumn{3}{|c|}{ Generality } \\
\hline & & Situational & Contextual & Global \\
\hline \multirow{2}{*}{ Quality } & Intrinsic & $x$ & 0 & $x$ \\
\hline & Extrinsic & $\times$ & $x$ & $x$ \\
\hline
\end{tabular}


Thus, motivation has a variety of qualities (e.g. intrinsic and extrinsic). In addition, as Vallerand and Rattel (2002) showed, motivation can be classified into three levels of generality (i.e. situational, contextual and global). Table 1 displays how motivation could be classified according to both generality and quality. In this study I addressed intrinsic motivation in contextual level, named intrinsic English Classroom motivation.

\section{Causal relationships}

Following Dörnyei (1994), Tanaka (2005a, 2006) further conceptualized Intrinsic English Classroom motivation with a theoretical underpinning from Self-determination theory (Deci \& Ryan, 2000; Ryan \& Deci, 2002). Self-determination theory is one of the most useful theories because it clearly shows what facilitates learners' intrinsic motivation.

The theory posits three psychological needs to facilitate intrinsic motivation. These are the need for autonomy, competence, and relatedness. Autonomy is referred to as "being the perceived origin or source of one's own behaviour" (Ryan \& Deci, 2002, p. 8) and learners feel autonomous when they experience a sense of control, agency, or self-determination. Competence is defined as "feeling effective in one's ongoing interactions with the social environment and experiencing opportunities to exercise and express one's capacities" (Ryan \& Deci, 2002, p. 7). Relatedness is defined as a sense of belongingness and connectedness toward other persons (for example, teachers or students) or a group (for example, a peer group or class).

These causal relationships between psychological needs and intrinsic English Classroom motivation have been empirically supported in the Japanese EFL context. Tanaka (2005b) administered a survey targeting Japanese high school students. Intrinsic English classroom motivation was assessed at two different times and causal analysis was conducted to reveal which psychological needs contributed to motivational change during the period. The results showed that competence was the strongest facilitating factor among the psychological needs.

However, Tanaka's study did not address attitudinal variables and it is not clear whether motivational enhancement by satisfaction of psychological needs really leads to students' active classroom engagement. Consequently, this study aims to empirically test the causal relationships of psychological needs, intrinsic English classroom motivation, and classroom engagement.

\section{Purpose}

The purpose of this study was to examine the facilitating factors of students' classroom engagement and intrinsic English classroom motivation. In particular, the causal relationships among between psychological needs, intrinsic English classroom motivation, and classroom engagement were examined. 


\section{Method \\ Participants}

The participants were 69 high school students ( 49 boys and 20 girls). Their ages ranged from 15 to 16. None of them had been abroad longer than one year.

\section{Procedure}

A questionnaire for assessing psychological needs, intrinsic English classroom motivation and classroom engagement was administered. I distributed the questionnaire and made sure that the survey was voluntary, students' answers were completely confidential, and the results were used only for research purposes. The questionnaire was collected after I had confirmed that the learners had completed it. All data were collected in the English Course 1 class. The teacher, textbooks, and teaching method were the same for all classes.

The material used in this study consisted of a questionnaire consisting three sections. A brief description of the questionnaire and its Cronbach alpha indices are given below.

\section{Materials}

For assessing psychological needs (autonomy competence and relatedness), a scale was designed based on the Basic Psychological Needs Scale (Deci \& Ryan, 2000). It includes autonomy ( $\alpha=.80$, e.g. In this class, our teacher gives us a freedom of choice on materials, contents of learning, and a course design), competence ( $\alpha=.83$, e.g. In this class, I can study English without feeling a pressure.) and relatedness ( $\alpha=.73$, e.g. In this class, I can get along well with my classmates.). Each scale was composed of three items. Learners rated the extent to which each description corresponded to their own impressions of their English class. The validity of the scale was supported by a preliminary survey targeting Japanese EFL learners (Hiromori \& Tanaka, 2006). I used a seven-point scale ranging from one (I do not agree at all) to seven (I completely agree).

Intrinsic English classroom motivation was measured by four items (e.g. "I find this class interesting." and "I am looking forward to attending this class"). The reliability of the scale was acceptable $(\alpha=.78)$. The validity of these items was previously tested targeting high school students by using confirmatory factor analysis (Tanaka, 2005a, 2006).

Classroom Engagement was assessed by 4 items ("In this class, I try to stay awake.", "I engage in this class enthusiastically", "In this class, I study English hard.", and "In this class, I concentrate on studying English."). The reliability of the scale was also acceptable $(\alpha=.95)$.

\section{Data analysis}

Descriptive statistics and correlational coefficients were calculated using SPSS 15.0J. Causal analysis was conducted by specifying and testing a structural equation model using Amos 7.0. 


\section{Results}

I computed descriptive statistics and a Pearson product-moment correlation matrix on psychological needs, intrinsic English classroom motivation, and classroom engagement. The results of descriptive statistics are shown in Table 1, and the correlational analysis in Table 2.

The descriptive statistics revealed that students in this class felt satisfied with their needs for autonomy $(M=4.20)$ and relatedness $(M=4.56)$, though their satisfaction with the need for competence was not high $(M=3.57)$. The result also showed that students' intrinsic English classroom motivation was not high $(M=3.69)$, but they engaged in the English class rather actively $(M=4.34)$.

Table 1.

Descriptive statistics of the psychological needs, intrinsic English Classroom motivation and classroom engagement.

\begin{tabular}{ccccccc}
\hline & & $N$ & $k$ & $M$ & $S D$ & $\alpha$ \\
\hline \multirow{4}{*}{ Psychological needs } & Autonomy & 69 & 3 & 1.08 & 4.20 & .80 \\
& Competence & 69 & 3 & 1.13 & 3.57 & .83 \\
& Relatedness & 69 & 3 & 1.00 & 4.56 & .75 \\
Classroom engagement & 69 & 4 & 4.34 & 1.50 & .95 \\
English classroom motivation & 69 & 4 & 3.69 & 1.00 & .78 \\
\hline
\end{tabular}

The correlational coefficients showed that intrinsic English Classroom motivation correlated most highly with competence $(r=.67)$. The correlational coefficients of the other psychological needs were not as high (autonomy $r=.40$, relatedness $r=.34$ ). Classroom engagement was significantly correlated with intrinsic English Classroom motivation $(r=.65)$.

Table 2.

Correlational coefficients of the scales for psychological needs, intrinsic English classroom motivation and classroom engagement.

\begin{tabular}{ccccccc}
\hline & & Autonomy & Competence & Relatedness & Engagement & Motivation \\
\hline & Autonomy & - &. & & & \\
Psychological & Competence & $.48^{*}$ & - & & & \\
needs & Relatedness & .02 & .06 & - & & \\
Classroom engagement & $.24^{*}$ & $.58^{*}$ & $.38^{*}$ & - & \\
English classroom motivation & $.40^{*}$ & $.67^{*}$ & $.34^{*}$ & $.65^{*}$ & - \\
\hline
\end{tabular}

Note. ${ }^{*} p<.05$.

In order to obtain a clearer picture of the relationships among psychological needs, Intrinsic 
English Classroom motivation and engagement, I further conducted a causal analysis using structural equation modeling. The measurement model had an acceptable fit $\chi^{2}=169.237, p$ $=.00, d f=112, \mathrm{CFI}=.923, \mathrm{IFI}=.925, \mathrm{TLI}=.906, \mathrm{GFI}=.790)^{2}$.

The results are shown in Figure 1 and Table 3. It showed that competence had the strongest effect on intrinsic English Classroom motivation (.80) compared to autonomy (-.05) and relatedness (.41). The path coefficient from autonomy to motivation was not significant at $p$ $<.05$, though it had an indirect effect on motivation through competence (.45). Motivation had a strong direct effect on classroom engagement (.80). The indirect effect of competence on classroom engagement was the strongest (.64) of the three psychological needs.

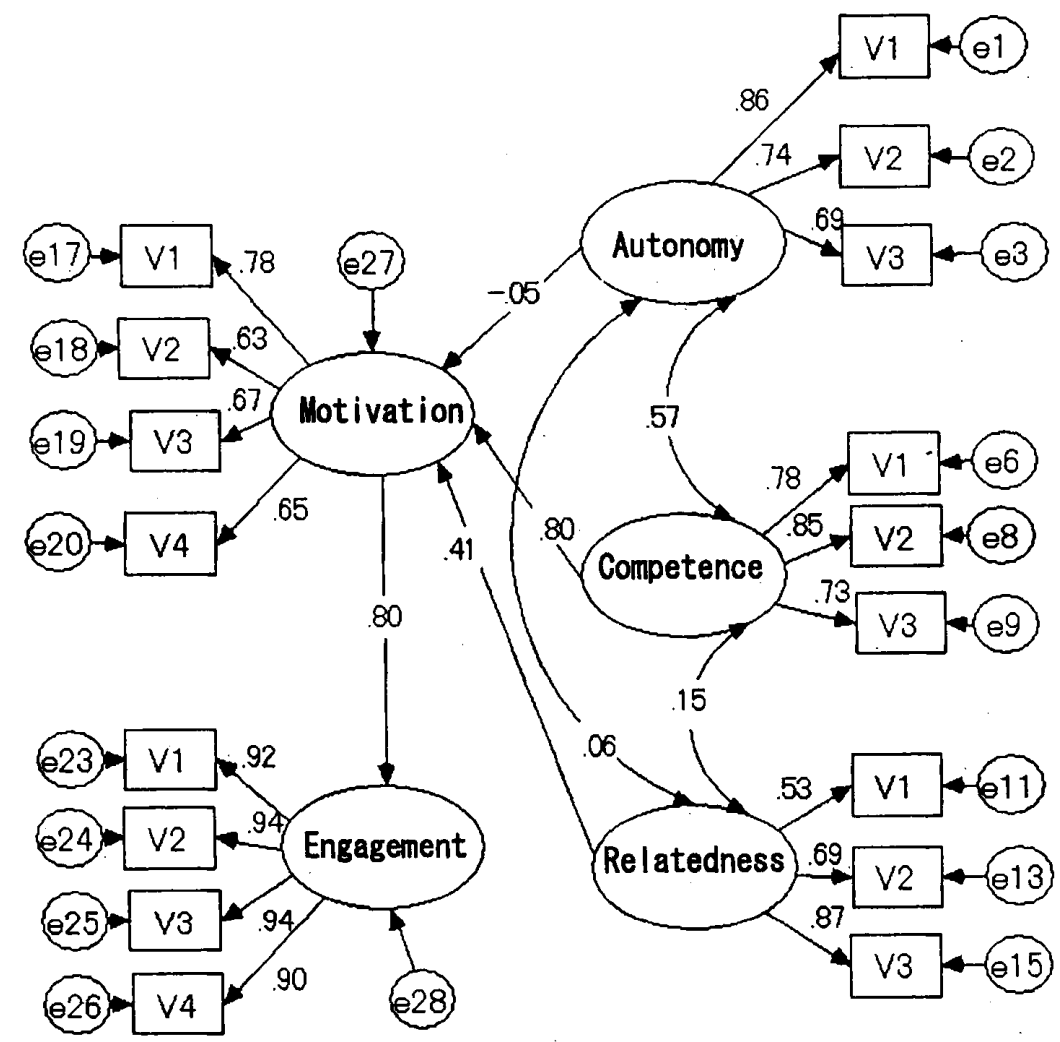

Figurel. The causal relationships between psychological needs, intrinsic English classroom motivation and engagement

Table 3.

The direct and indirect effects of the three psychological needs and intrinsic English classroom motivation.

\begin{tabular}{ccccc}
\hline & Autonomy & Competence & Relatedness & $\begin{array}{c}\text { English classroom } \\
\text { motivation }\end{array}$ \\
\hline English classroom motivation & -.05 & $.80^{*}$ & $.41^{*}$ & - \\
Classroom engagement & -.04 & $.64^{*}$ & $.32^{*}$ & $.80^{*}$ \\
\hline
\end{tabular}

Note. ${ }^{*} p<.05$. 


\section{Discussion}

Motivation research focusing on how to activate students' classroom engagement has been a rather neglected area. To achieve the research purpose, I addressed motivation at the contextual level, named intrinsic English classroom motivation with the theoretical underpinning of Self-determination theory and the hierarchical model. The current study dealt with the relationship between three psychological needs and classroom engagement mediated by intrinsic English classroom motivation. I analyzed the data by using correlational coefficients and structural equation modeling.

The result of this study revealed that satisfaction of the need for competence was the strongest facilitating factor of classroom engagement. The causal analysis showed that competence has the strongest indirect effect on classroom engagement (.64). The result also indicated that relatedness has an indirect effect on classroom engagement (.33). Thus, feeling competent and connected to relevant others such as teachers and classmates enhances students' motivation and triggers energized behavior. Teachers who successfully nurture their students' sense of competence and relatedness gain an opportunity to develop a classroom full of intrinsically motivated, active, and engaged students. Thus, the findings of the study lead to the conclusion that the key factors for facilitating students' intrinsic classroom motivation and classroom engagement were competence and relatedness.

Then, how can teachers make their students feel competent and connected to others? Connell and Skinner's theoretical model (Connell, 1990; Connell \& Wellborn, 1991; Furrer \& Skinner, 2003; Skinner \& Belmont, 1993) provides further information about how teachers can create an engagement-facilitating classroom climate.

In their model, students' need for competence is satisfied by providing structure in the classroom. Structure refers to "the amount and clarity of information the teacher provides to students about how to achieve desired academic and behavioral outcomes" (Reeve, 2002, p.205). This means that when teachers provide clear expectations, contingent responses, and strategic help, students become enthusiastic in class (Skinner \& Belmont, 1993). Second, what is important for satisfaction of the students' need for relatedness is involvement. Involvement refers to "the quality of the interpersonal relationships with teachers and peers" (Skinner \& Belmont, 1993, p.572). This means that when students perceive their teachers to have affection for and interest in them, students show active engagement in the English class (Connell, 1990; Connell \& Wellborn, 1991).

The current study also showed that competence has the strongest direct effect on intrinsic English classroom motivation. It is noted, however, that participants' satisfaction of the need for competence was the lowest among the three needs. The mean score of competence was $M=$ 3.57, while autonomy was $M=4.20$ and relatedness was $M=4.56$. It is not clear whether the strongest direct effect of competence on intrinsic English classroom motivation is a general tendency of Japanese high school students or can be attributed to participants' comparatively low sense of competence. However, preceding studies have confirmed the importance of the 
students' sense of competence to facilitate their intrinsic English Classroom motivation (Tanaka, 2005b). Thus, the result of the current study provides further empirical support for the importance of satisfying students' competence in the classroom. For greater generalizability, further investigations would be needed.

This study provides empirical support for applying Self-determination theory to the Japanese EFL context. Though several studies have shown that Self-determination theory is a useful theoretical tool for facilitating Japanese EFL learners' trait motivation with empirical evidence, the theory still lacks empirical support in terms of motivation in the specific context. In the current study, intrinsic English Classroom motivation was defined in terms of intrinsic motivation at the contextual level with reference to the hierarchical model, and the results indicated that intrinsic English Classroom motivation can be facilitated by satisfaction of the need for competence and relatedness.

With regard to the need for autonomy, this study showed a result that was rather contradictory to the prediction of Self-determination theory. The theory emphasizes that satisfaction of the need for autonomy is essential to facilitate intrinsic motivation, but the result did not indicate any significant effect. Due to the limited sample size, it would be safer to interpret this contradiction as the result of this case study and not as a general tendency of Japanese EFL learners.

However, it would be interesting to note that this contradictory result conforms to Kitayama and Miyamoto's (2000) theoretical prediction. They posed the question of the importance of autonomy in a Japanese context compared to North America, where most of the studies on Self-determination theory have been conducted. They attributed a less prominent role of autonomy to the difference in the construal of the self between Asians and North Americans. According to their theory, North Americans have an independent construal of self. This means that North American people typically seek to maintain their independence from others, to become autonomous, and to express their unique attributes (Markus \& Kitayama, 1991; Triandis, 1995). Thus, satisfying the need for autonomy is quite important for them. On the other hand, Japanese people tend to have an interdependent construal of self. This means that Japanese people insist on connectedness to, and fitting in with each other, and their "expression and the experience of emotions and motives may be significantly shaped and governed by a consideration of the reactions of others" (Murkus \& Kitayama, 1991, p225). Thus Japanese people tend to put an emphasis on satisfying the need for relatedness rather than the need for autonomy. Kitayama's theoretical predictions have been empirically supported by several studies targeting Asian (Iyengar \& Lepper, 1999) and Japanese EFL learners (Hiromori, 2003; Tanaka, 2005b). More detailed research would be required in order to examine these relationships. 


\section{Future directions}

There are five limitations in this study.

First, future research would benefit from more elaborate measurement of classroom engagement. This study assessed classroom engagement using a students' self-report questionnaire. It would be valuable to add observation or behavioral indicators to capture a more dynamic picture of students' classroom engagement and motivation.

In addition to the issues of measurement, one of the main limitations of this study was contextual dependency. Intrinsic English Classroom motivation is a contextual aspect of motivation. Thus, for more generalizability of the result, building up further studies on different contexts would be needed.

Third, the result of structural equation modeling would be affected by sample size. Tabachnick and Fidell (2001) suggest a sample size of 200 or more for structural equation modeling. Although the model tested in this study appears to fit the data reasonable well, testing the model with a larger sample is necessary to insure that the estimated population parameters are accurate and stable.

Forth, to reveal more complex picture of motivation, qualitative studies is quite useful. For future direction, it is important to combine the quantitative and qualitative studies.

Finally, I defined intrinsic English Classroom motivation with theoretical underpinning of Self-determination theory. However, Self-determination theory is just one theory of motivation. Other theoretical conceptualizations of intrinsic English Classroom motivation are important for future research.

Note

1. This is a scenario that illustrates the motivational complexity in classroom. This type of illustration is often used in motivational literature (e.g. Pintrich \& Shank, 2002).

2. Although the chi square test indicated a significant difference between the sample data and the estimated population parameters, comparative fit statistics indicate that the model provides a reasonable approximation of the effects in the population.

\section{References}

Connell, J. P. (1990). Context, self, and action: A motivational analysis of self-system processes across the life span. In D. Cicchetti \& M. Beeghly (Eds.), The self in transition: Infancy to childhood (pp. 61-97). Chicago, IL: University of Chicago Press.

Connell, J. P., \& Wellborn, J. G. (1991). Competence, autonomy and relatedness: A motivational analysis of self-system processes. In M. R. Gunnar \& L. A. Sroufe (Eds.), Minnesota symposium on child psychology (Vol. 23, pp. 43-77). Chicago, IL: University of Chicago Press. Deci, E. L., \& Ryan, R. M. (2000). The "what" and "why" of goal pursuits: Human needs and 
the self-determination of behavior. Psychological Inquiry, 11, 227-268.

Deci, E. L., \& Ryan, R. M. (2002). Handbook of Self-determination research. Rochester, NY:

University of Rochester Press.

Dörnyei, Z. (1994). Motivation and motivating in the foreign language classroom. The Modern Language Journal, 78, 273-284.

Dörnyei, Z. (2001). Teaching and researching motivation. Harlow: Longman.

Emmons, R. A. (1995). Levels and domains in personality: An introduction. Journal of Personality, 63, 341-364.

Fridhandler, B. M. (1986). A conceptual note on state, trait, and the state-trait distinction. Journal of Personality and Social Psychology, 50, 169-174.

Furrer, C, \& Skinner, E. (2003). Sense of relatedness as a factor in children's academic engagement and performance. Journal of Educational Psychology. 95, 148-161.

廣森友人. (2003). 「学習者の動機づけは何によって高まるのか: 自己決定理論による 高校生英語学習者の動機づけの検討」.JALT Journal, 25, 173-186.

廣森友人・田中博晃. (2006). 「英語学習における動機づけを高める授業実践: 自己決 定理論の視点から」. Language Education and Technology, 43, 111-126.

Iyengar, S. S., \& Lepper, M. R. (1999). Rethinking the role of choice: A cultural perspective on intrinsic motivation. Journal of Personality and Social Psychology, 76, 349-366.

Kimura, Y., Nakata, Y., \& Okumura, T. (2001). Language learning motivation of EFLlearners in Japan-a cross-sectional analysis of various learning milieus. JALT Journal, 23, 47-68.

北山忍 - 宮本百合. (2000). 「文化心理学と洋の東西の巨視的比較一現代的意義と実証 的知見」。『心理学評論』, 43, 57-81.

Markus, H. R., \& Kitayama, S. (1991). Culture and the self: Implication for cognition, emotion, and motivation. Psychological Review, 98, 224-253.

Reeve, J. (2002). Self-determination theory applied to educational settings. In E. L. Deci \& R. M. Ryan (Eds.), Handbook of self-determination research. (pp. 183-204). Rochester, NY: University of Rochester Press.

Ryan, R. M., \& Deci, E. L. (2002). An overview of Self-determination theory: An organismic-dialectical perspective. In E. L. Deci \& R. M. Ryan (Eds.), Handbook of self-determination research. (pp. 3-36). Rochester, NY: University of Rochester Press.

Skinner, E. A., \& Belmont, M. J. (1993). Motivation in the classroom: Reciprocal effects of teacher behavior and student engagement across the school year. Journal of Educational Psychology, 85, 571-581.

Spielberger, C. D., Auerbach, S. M., Wadsworth, A. O., Dunn, T. M., \& Taulbee, E. S. (1973). Emotional reactions to surgery. Journal of Consulting and Clinical Psychology, 40, 33-38.

Tabachnick, B. G., \& Fidell, L. S. (2001). Using multivariate statistics. Boston, MA: Allyn \& Bacon.

田中博晃. (2005a).「「英語授業への動機づけ」の概念化：高校生を対象にした検討」. 『中国地区英語教育学会研究紀要』, 35, 37-46. 
田中博晃. (2005b). 「英語授業への動機づけを高める要因の検討: 自己決定理論におけ る 3 欲求の観点から」。『第 31 回全国英語教育学会札幌研究大会予稿集』, 426-427.

田中博晃. (2006). 「英語授業への動機づけ」と英語学習一般への動機づけ：因果関係 の検討」。『中国地区英語教育学会研究紀要』, 36, 41-48.

田中博晃・廣森友人. (2007). 「英語学習者の内発的動機づけを高める教育実践的介入 とその効果の検証」.JALT Journal, 29, 59-80.

Tremblay, P. F., Goldberg, M. P., \& Gardner, R. C. (1995). Trait. and state motivation and the acquisition of Hebrew vocabulary. Canadian Journal of Behavioural Science, 27, 356-370.

Triandis, H. C. (1995). Individualism and collectivism. San Francisco, CA: Westview Press.

Vallerand, R. J., \& Ratelle, C. F. (2002). Intrinsic and extrinsic motivation: A hierarchical model. In E. L. Deci, \& R. M. Ryan (Eds.), Handbook of Self-determination research (pp. 37-64). Rochester, NY: University of Rochester Press.

Vallerand, R. J., \& Ratelle, C. F. (2002). Intrinsic and extrinsic motivation: A hierarchical model. In E. L. Deci, \& R. M. Ryan (Eds.), Handbook of Self-determination research (pp. 37-64). Rochester, NY: University of Rochester Press. 
Appendix. Questionnaire used in this study.

「英語学習の取り組み」に関するアンケート

I あなたの英語学習に対する動機や理由に関して，教えてください。以下の基準で，該当する数字 を○で囲んでください。

$\begin{array}{lllllll}1 & 2 & 3 & 4 & 5 & 6 & 7\end{array}$

まったくちがう ちがう ややちがうどちらでもないややそのとおりそのとおりまったくそのとおり

\begin{tabular}{|c|c|}
\hline $\begin{array}{c}1 . \text { この授業では, 教材・授業の進め方・学習内容に関して, 私た } \\
\text { ち/僕たちにある程度の選択の自由が，与えられていると思う。 }\end{array}$ & $(1 \cdot 2 \cdot 3 \cdot 4 \cdot 5 \cdot 6 \cdot 7)$ \\
\hline 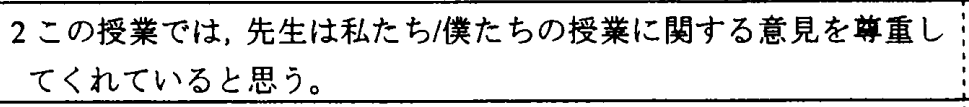 & $(1 \cdot 2 \cdot 3 \cdot 4 \cdot 5 \cdot 6 \cdot 7)$ \\
\hline 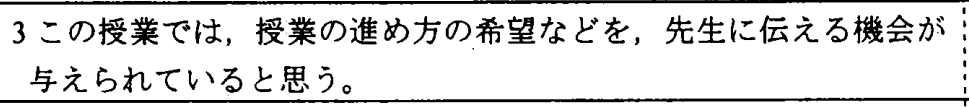 & $(1 \cdot 2 \cdot 3 \cdot 4 \cdot 5 \cdot 6 \cdot 7)$ \\
\hline $\begin{array}{l}4 \text { この授業では, プレッシャーを感じずに勉強をすることができる } \\
\text { と思う。 }\end{array}$ & $(1 \cdot 2 \cdot 3 \cdot 4 \cdot 5 \cdot 6 \cdot 7)$ \\
\hline 5この授業では，「できた」という達成感が得られると思う。 & $(1 \cdot 2 \cdot 3 \cdot 4 \cdot 5 \cdot 6 \cdot 7)$ \\
\hline $\begin{array}{l}6 \text { この授業では, 先生やクラスメイトから「よくできた」と誉めら } \\
\text { れるなど，良い評価をしてもらえると思う。 }\end{array}$ & $(1 \cdot 2 \cdot 3 \cdot 4 \cdot 5 \cdot 6 \cdot 7)$ \\
\hline 7この授業では,「よくがんばった」という満足感が得られると思う。 & $(1 \cdot 2 \cdot 3 \cdot 4 \cdot 5 \cdot 6 \cdot 7)$ \\
\hline $\begin{array}{l}8 こ の \text { 授業では，自分の努力の成果が実ったという充実感が得られ } \\
\text { ることがあると思う。 }\end{array}$ & $(1 \cdot 2 \cdot 3 \cdot 4 \cdot 5 \cdot 6 \cdot 7)$ \\
\hline 9 この授業では，同じ教室の仲閒と仲良くやっていると思う。 & $(1 \cdot 2 \cdot 3 \cdot 4 \cdot 5 \cdot 6 \cdot 7)$ \\
\hline $\begin{array}{l}10 \text { この授業でのグループ活動・ペアワークでは，協力し合う察囲気 } \\
\text { があると思う。 }\end{array}$ & $(1 \cdot 2 \cdot 3 \cdot 4 \cdot 5 \cdot 6 \cdot 7)$ \\
\hline 11 この授業では，和気あいあいとした祭囲気があると思う。 & $(1 \cdot 2 \cdot 3 \cdot 4 \cdot 5 \cdot 6 \cdot 7)$ \\
\hline 12 この授業では，同じ教室の仲間同士で学びあう等囲気があると思う。 & $(1 \cdot 2 \cdot 3 \cdot 4 \cdot 5 \cdot 6 \cdot 7)$ \\
\hline 13 この授業は，おもしろいと思う。 & $(1 \cdot 2 \cdot 3 \cdot 4 \cdot 5 \cdot 6 \cdot 7)$ \\
\hline 14 この授業は，楽しくて時間が過ぎるのが早いと感じる。 & $(1 \cdot 2 \cdot 3 \cdot 4 \cdot 5 \cdot 6 \cdot 7)$ \\
\hline 15 この授業を，楽しみにしている。 & $(1 \cdot 2 \cdot 3 \cdot 4 \cdot 5 \cdot 6 \cdot 7)$ \\
\hline 16 この授業では，好奇心が刺激されると思う。 & $(1 \cdot 2 \cdot 3 \cdot 4 \cdot 5 \cdot 6 \cdot 7)$ \\
\hline 17 この授業では，居眠りしないようにしている。 & $(1 \cdot 2 \cdot 3 \cdot 4 \cdot 5 \cdot 6 \cdot 7)$ \\
\hline 18 この授業では，熱心に取り組んでいる。 & $(1 \cdot 2 \cdot 3 \cdot 4 \cdot 5 \cdot 6 \cdot 7)$ \\
\hline 19 この授業では, がんばって勉強している。 & $(1 \cdot 2 \cdot 3 \cdot 4 \cdot 5 \cdot 6 \cdot 7)$ \\
\hline 20 この授業では，集中できている。 & $(1 \cdot 2 \cdot 3 \cdot 4 \cdot 5 \cdot 6 \cdot 7)$ \\
\hline
\end{tabular}

Note. For English translation, refer to "Materials". 